\title{
HUBUNGAN ANTARA PENGETAHUAN DAN SIKAP PENDERITA HIPERTENSI TERHADAP KEAKTIFAN PESERTA BPJS DI UPT PUSKESMAS MERDEKA KOTA BOGOR TAHUN 2018
}

\author{
Siti Rohimah Kumullah', Indira Chotimah ${ }^{2}$ \\ ${ }^{1}$ Konsentrasi Manajemen Pelayanan Kesehatan, Program Studi Kesehatan Masyarakat Fakultas Ilmu Kesehatan, \\ Universitas Ibn Khaldun Bogor, Jl. K.H Soleh Iskandar KM 2, Kota Bogor, 16162. Email : s.rohimah20@yahoo.co.id \\ ${ }^{2}$ Konsentrasi Manajemen Pelayanan Kesehatan, Program Studi Kesehatan Masyarakat Fakultas Ilmu Kesehatan, \\ Universitas Ibn Khaldun Bogor, Jl. K.H Soleh Iskandar KM 2, Kota Bogor, 16162. \\ Email : indira.chotimah@gmail.com
}

\begin{abstract}
Abstrak
Menurut WHO, tekanan darah yang normal bagi orang dewasa adalah 120/80 mmHg. Akan tetapi, jika tekanan darah sistolik yaitu antara 130-139 dan tekanan darah distolik antara 8089, dan itu juga masih bisa disebut dengan tekanan darah yang normal. Program Pengelolaan Penyakit Kronis (prolanis) adalah suatu sistem pelayanan kesehatan dan pendekatan proaktif yang dilaksanakan secara terintegrasi yang melibatkan peserta, fasilitas kesehatan dan BPJS Kesehatan dalam rangka pemeliharaan kesehatan bagi peserta BPJS Kesehatan yang menderita penyakit kronis untuk mencapai kualitas hidup yang optimal dengan biaya pelayanan kesehatan yang efektif dan efisien.Penelitian ini menggunakan metode penelitian kuantitatif dan pengambilan data dilakukan dengan desain Cross Sectional dengan menggunakan kuesioner. Jumlah sampel dalam penelitian ini adalah 49 responden. Cara analisa data menggunakan perangkat lunak aplikasi statistik.Hasil penelitian menunjukan bahwa sebagian besar responden memiliki pengetahuan tidak baik mengenai program pengelolaan penyakit kronis (Prolanis) (61.2\%), sikap yang positif mengenai program pengelolaan penyakit kronis (Prolanis) (59.2\%), keluarga yang memberikan dukungan dalam keaktifan penderita sebagian besar mendukung (63.3\%). Berdasarkan tingkat keaktifan penderita hipertensi sebagian besar (51.0\%) termasuk kedalam kategori aktif dalam kegiatan Prolanis. Hasil analisis menunjukan bahwa Terdapat hubungan antara pengetahuan dengan keaktifan penderita hipertensi dalam kegiatan prolanis $(p$-value $=0.035)$. Tidak terdapat hubungan antara umur ( $p$-value $=1000)$, Jenis kelamin $(p$-value $=0.716)$, Pendidikan ( $p$-value $=1000)$, Sikap ( $p$-value $=0.863)$, dan Dukungan keluarga $(p$-value $=0.053)$ dengan keaktifan penderita hipertensi dalam kegiatan prolanis. Peneliti memberikan saran kepada Puskesmas Merdeka Kota Bogor untuk meningkatkan keaktifan masyarakat perlu direncanakan dan member tugas kepada sebagian petugas kesehatan di puskesmas untuk melakukan kunjungan home visit kerumah pasien, sehingga 4 aktivitas prolanis bisa berjalan maksimal. Kata kunci : Pengetahuan, Sikap, Hipertensi, Keaktifan, Prolanis.
\end{abstract}




\section{PENDAHULUAN}

Menurut World Health Organization (WHO) penyakit tidak menular (PTM) merupakan penyakit dengan durasi panjang yang pada umumnya berkembang secara lambat. Penyakit tidak menular membunuh 38 juta orang di seluruh dunia setiap tahunnya. Sebanyak 28 juta orang $(75 \%)$ korbannya berasal dari Negara berpendapatan rendah dan sedang. Kematian akibat penyakit tidak menular sebanyak 16 juta orang terjadi sebelum usia 70 tahun. Ada empat kelompok penyakit tidak menular yang menjadi penyebab utama kematian, yaitu : penyakit kardiovaskular $(46 \%)$, berbagai jenis kanker $(21,6 \%)$, penyakit pernapasan kronis (10,5\%), dan diabetes (4\%) (WHO, 2015).

Menurut WHO, tekanan darah yang normal bagi orang dewasa adalah 120/80 mmHg. Akan tetapi, jika tekanan darah sistolik yaitu antara 120-139 dan tekanan distolik antara 8089, dan itu juga masih bisa di sebut dengan tekanan darah yang normal. WHO mencatat pada tahun 2013 sedikitnya sejumlah 839 juta kasus hipertensi, diperkirakan menjadi 1,15 milyar pada tahun 2025 atau sekitar 29\% dari total penduduk dunia, dimana penderitanya lebih banyak pada wanita (30\%) dibanding pria (29\%). Sekitar 80\% kenaikan kasus hipertensi terjadi terutama di negara- negara berkembang (Triyanto, 2014).

Badan Kesehatan Dunia (WHO) menyebutkan jumlah penderita hipertensi akan terus meningkat seiring dengan jumlah penduduk yang bertambah pada 2025 mendatang diperkirakan sekitar 29\% warga dunia terkena hipertensi. WHO menyebutkan negara ekonomi berkembang memiliki penderita hipertensi sebesar 40\% sedangkan negara maju 35\%, kawasan Afrika memegang posisi puncak penderita hipertensi, yaitu sebesar 40\%. Kawasan Amerika sebesar 35\% dan Asia Tenggara 36\%. Kawasan Asia penyakit ini telah membunuh 1.5 juta orang setiap tahunnya. Hal ini menandakan satu dari tiga orang menderita hipertensi. Sedangkan di Indonesia cukup tinggi, yakni mencapai 32\% dari total jumlah penduduk.

Hasil Riset Kesehatan Dasar menunjukan terjadi peningkatan penyakit tidak menular di Indonesia dari tahun 2007 hingga 2013. Peningkatan prevalensi penyakit tidak menular yaitu : diabetes mellitus (DM) cenderung naik dari 1,1\% pada tahun 2007 menjadi 2,1\% pada tahun 2013, hipertensi cenderung mengalami kenaikan dari 7,6\% pada tahun 2007 menjadi 9,5\% pada tahun 2013, dan stroke dari 8,3 per mil tahun 2007 menjadi 12,1 per mil pada tahun 2013 (Kemenkes RI, 2013).

Penyakit tidak menular yang sedang diperhatikan di kesehatan dunia adalah Penyakit Diabetes dan Hipertensi. Menurut penelitian Rondonuwu dkk, (2016) menyatakan diabetes mellitus adalah suatu kumpulan gejala yang timbul pada seseorang yang disebabkan oleh karena adanya peningkatan kadar gula (glukosa) darah akibat kekurangan insulin yang baik absolute maupun relatif. Olahraga atau aktivitas fisik berguna sebagai pengendali kadar gula darah dan penurunan berat badan pada penderita diabetes mellitus. Dari hasil yang sudah dilakukan didapati perilaku olahraga paling banyak yaitu pada kategori sedang. Dari hasil penelitian yang sudah dilakukan didapati kadar glukosa darah sewaktu paling banyak pada kategori normal. Ada hubungan antara perilaku olahraga dengan kadar gula darah penderita diabetes melitus.

Prevalensi hipertensi di Jawa Barat berdasarkan hasil pengukuran tekanan darah adalah $29,3 \%$, dan hanya berdasarkan diagnosis oleh tenaga kesehatan adalah 9,5\%, sementara 
berdasarkan diagnosis dan atau riwayat minum obat hipertensi adalah 9,9\%. Menurut Kabupaten/Kota, hipertensi berdasarkan tekanan darah berkisar antara 22,5\% - 43,1\%, prevalensi tertinggi di Kabupaten Tasikmalaya dan terendah di Kabupaten Karawang. Sementara prevalensi hipertensi berdasarkan diagnosis oleh tenaga kesehatan dan atau minum obat hipertensi berkisar antara 6,9\% - 12,4\%. Memperhatikan angka prevalensi hipertensi berdasarkan diagnosis atau minum obat dibandingkan dengan prevalensi hipertensi berdasarkan hasil pengukuran tekanan darah di setiap Kabupaten/Kota di Jawa Barat, pada umumnya nampak perbedaan prevalensi yang cukup besar. Perbedaan prevalensi paling besar ditemukan di Kabupaten Kuningan. Data ini menunjukan banyak kasus hipertensi di masyarakat, baik di Kabupaten Kunngan maupun di wilayah kerja lainnya di Jawa Barat belum ditanggulangi dengan baik (Riskesdas Provinsi Jawa Barat, 2014).

Berdasarkan data profil kesehatan Kota Bogor Tahun 2015 dari sepuluh penyakit utama di Kota Bogor terlihat dari umur, hipertensi merupakan penyakit dengan jumlah kasus kedua tertinggi yaitu sebesar 29.990 kasus dibandingkan penyakit lainnya (Profil Kesehatan Kota Bogor, 2015). Tujuan dari penelitaian ini untuk mengetahui hubungan antara pengetahuan dan sikap penderita hipertensi terhadap keaktifan peserta BPJS dalam kegiatan prolanis di UPT Puskesmas Merdeka Kota Bogor. Sasaran utama penelitian ini adalah penderita hipertensi yang berada diwilayah kerja Puskesmas Merdeka. Penelitian ini dilakukan pada Bulan Oktober 2018. Penelitian ini dilihat dari beberapa faktor yaitu faktor penguat, dan pendukung (terdapat aspek pengetahuan, sikap,dan dukungan keluarga). Adapun pengambilan data diperoleh dari penyebaran angket kuesioner.

\section{METODE}

Penelitian ini mengunakan metode kuantitaif dengan metode cross sectional dipilih secara purposive sampling. Penelitian ini dilakukan di UPT Puskesmas Merdeka Kota Bogor pada Tahun 2018. Populasi dalam penelitian ini adalah seluruh penderita hipertensi di Wilayah Kerja Puskesmas Merdeka Kota Bogor Tahun 2018. Penelitian ini teknik pengambilan sampel menggunakan Purpose sampling yaitu tehnik penentuan sampel diambil menurut kriteria tertentu

\section{Hasil Penelitian Analisis Univariat}

Karakteristik responden Penelitian Distribusi umur penderita Hipertensi di wilayah Puskesmas Merdeka adalah sebagai berikut:

Tabel 1 Distribusi Frekuensi Umur

\begin{tabular}{ccc}
\hline Umur & Frekuensi & $\begin{array}{c}\text { Persentase } \\
(\%)\end{array}$ \\
\hline Usia Produktif (15-55) & 6 & 12.2 \\
\hline $\begin{array}{c}\text { Usia Non- Produktif } \\
(>55)\end{array}$ & 43 & 87.8 \\
\hline Total & $\mathbf{4 9}$ & $\mathbf{1 0 0 . 0}$ \\
\hline
\end{tabular}

Sebagian besar pasien penderita hipertensi di wilayah Puskesmas Merdeka Kota Bogor 
berada pada usia Non-Produktif ( $>55)$, selanjutnya hasil distribusi data frekuensi berdasarkan jenis kelamin sebagai berikut:

Tabel 2 Distribusi Ftekuensi Jenis Kelamin

\begin{tabular}{ccc}
\hline Jenis kelamin & Frekuensi & Persentase (\%) \\
\hline Perempuan & 38 & 77.6 \\
\hline Laki-laki & 11 & 22.4 \\
\hline Total & $\mathbf{4 9}$ & $\mathbf{1 0 0 . 0}$
\end{tabular}

Sebagian besar pasien penderita hipertensi di wilayah Puskesmas Merdeka Kota Bogor mempunyai jenis kelamin perempuan, selanjutnya hasil distribusi data berdasarkan pendidikan sebagai berikut :

Tabel 3 Distribusi Frekuensi Pendidikan

\begin{tabular}{ccc}
\hline Pendidikan & Frekuensi & $\begin{array}{c}\text { Persentase } \\
(\%)\end{array}$ \\
\hline $\begin{array}{c}\text { Pendidikan Rendah } \\
\text { (SD,SMP,SMA) }\end{array}$ & 35 & 71.4 \\
\hline $\begin{array}{c}\text { Pendidikan Tinggi } \\
\text { (D3 \& S1) }\end{array}$ & 14 & 28.6 \\
\hline Total & $\mathbf{4 9}$ & $\mathbf{1 0 0 . 0}$
\end{tabular}

Sebagian besar penderita hipertensi di wilayah Puskesmas Merdeka Kota Bogor mempunyai pendidikan terakhir pada tingkat pendidikan rendah (SD, SMP, SMA), selanjutnya hasil distribusi data berdasarkan tingkat pengetahuan penderita hipertensi sebagai berikut :

\begin{tabular}{ccc}
\multicolumn{2}{c}{ Tabel 4 Distribusi Frekuensi Pengetahuan } \\
\hline Pengetahuan & Frekuensi & $\begin{array}{c}\text { Persentase } \\
(\%)\end{array}$ \\
\hline Baik & 19 & 38.8 \\
\hline Tidak Baik & 30 & 61.2 \\
\hline Total & $\mathbf{4 9}$ & $\mathbf{1 0 0 . 0}$
\end{tabular}

Berdasarkan hasil penelitian tentang pengetahuan penderita hipertensi terhadap keaktifan dalam kegiatan prolanis di wilayah Puskesmas Merdeka Kota Bogor diketahui bahwa jumlah responden yang memberikan jawaban baik tentang pengetahuan sebanyak 19 responden (38.8\%). Sedangkan responden yang memberikan jawaban tidak baik tentang pengetahuan sebanyak 30 responden (61.2\%).

Distribusi data berdasarkan tingkat Sikap penderita hipertensi di wilayah Puskesmas Merdeka Kota Bogor adalah sebagai berikut : 
Tabel 5 Distribusi Frekuensi Sikap

\begin{tabular}{ccc}
\hline Sikap & Frekuensi & Persentase (\%) \\
\hline Setuju & 29 & 59.2 \\
\hline Tidak Setuju & 20 & 40.8 \\
\hline Total & $\mathbf{4 9}$ & $\mathbf{1 0 0 . 0}$
\end{tabular}

Berdasarkan hasil penelitian diketahui bahwa sikap penderita hipertensi terhadap keaktifan dalam kegiatan Prolanis di Puskesmas Merdeka Kota Bogor yang memiliki sikap setuju sebanyak 29 responden (59.0\%) dan yang memiliki sikap tidak setuju sebanyak 20 responden (40.8\%).

Distribusi data berdasarkan tingkat dukungan keluarga penderita hipertensi di wilayah Puskesmas Merdeka Kota Bogor adalah sebagai berikut :

Tabel 6 Distribusi Frekuensi Dukungan Keluarga

\begin{tabular}{ccc}
\hline $\begin{array}{c}\text { Dukungan } \\
\text { Keluarga }\end{array}$ & Frekuensi & $\begin{array}{c}\text { Persentase } \\
(\%)\end{array}$ \\
\hline Mendukung & 31 & 63.3 \\
\hline $\begin{array}{c}\text { Tidak } \\
\text { Mendukung }\end{array}$ & 18 & 36.7 \\
\hline Total & $\mathbf{4 9}$ & $\mathbf{1 0 0 . 0}$
\end{tabular}

Dukungan keluarga adalah pernyataan mengenai peran anggota yang dirasakan oleh responden terhadap pelayanan program lanjut usia, antara lain: menganjurkan untuk datang, mengingatkan jadwal, menemani dan mengantar ke tempat kegiatan program lanjut usia, dibagi menjadi 2 kategori yaitu adanya dukungan dan tidak mendukung. Berdasarkan hasil penelitian dapat diketahui bahwa penderita yang tidak mendapat dukungan dari keluarga sebanyak 18 responden (36.7\%).

Sedangkan penderita yang mendapat dukungan dari keluarga sebanyak 31 responden (63.3\%). Distribusi data berdasarkan tingkat keaktifan penderita hipertensi terhadap kegiatan prolanis di Puskesmas Merdeka Kota Bogor adalah sebagai berikut : 
Tabel 7 Distribusi Frekuensi Keaktifan

\begin{tabular}{ccc}
\hline Keaktifan & Frekuensi & $\begin{array}{c}\text { Persentase } \\
(\%)\end{array}$ \\
\hline Aktif & 25 & 51.0 \\
\hline Tidak Aktif & 24 & 49.0 \\
\hline Total & $\mathbf{4 9}$ & $\mathbf{1 0 0 . 0}$
\end{tabular}

Berdasarkan hasil diatas dapat diketahui bahwa sebagian besar 24 responden (49.0\%) termasuk kedalam kategori kurang aktif dalam kegiatan prolanis. Sedangkan 25 responden (51.0\%) termasuk ke dalam kategori aktif dalam kegiatan prolanis di Puskesmas Merdeka Kota bogor Tahun 2018.

Analisis bivariat dalam penelitian ini dilakukan dengan cara analisis Che Square, hasil penelitian tentang hubungan antar tingkat pengetahuan terhadap keaktifan penderita hipertensi dalam kegiatan prolanis di wilayah Puskesmas Merdeka Kota Bogor adalah sebagai berikut :

\section{Analisi Bivariat}

Tabel 8 Hubungan antara Pengetahuan Penderita Hipertensi terhadap keaktifan dalam kegiatan prolanis di Puskesmas Merdeka Kota Bogor

\begin{tabular}{|c|c|c|c|c|c|c|c|c|}
\hline \multicolumn{9}{|c|}{ Keaktifan } \\
\hline \multirow[t]{2}{*}{ Pengetahuan } & \multicolumn{2}{|c|}{$\begin{array}{r}\text { Tidak } \\
\text { Aktif }\end{array}$} & \multicolumn{2}{|c|}{ Aktif } & \multicolumn{2}{|c|}{ Total } & \multirow[t]{2}{*}{ P.Value } & \multirow[t]{2}{*}{ OR } \\
\hline & $\mathrm{N}$ & $\%$ & $\mathrm{~N}$ & $\%$ & $\mathrm{~N}$ & $\%$ & & \\
\hline Baik & 16 & $88.9 \%$ & 2 & $11.1 \%$ & 18 & 100.0 & & \\
\hline Tidak baik & 18 & $58.1 \%$ & 13 & $41.9 \%$ & 31 & 100.0 & 0.035 & $\begin{array}{c}6500(1.269- \\
33.290 \mathrm{CI})\end{array}$ \\
\hline Jumlah & 34 & $69.4 \%$ & 15 & $30.6 \%$ & 49 & & 100 & \\
\hline
\end{tabular}

Berdasarkan hasil diatas dapat diketahui bahwa hubungan antara pengetahuan dengan tingkat keaktifan responden dalam kegiatan prolanis yang mempunyai tingkat keaktifan aktif yaitu sebanyak 15 responden, dimana 2 responden atau $11.1 \%$ memiliki pengetahuan baik dan 13 responden atau 41.9\% memiliki pengetahuan kurang atau tidak baik. Sedangkan responden yang mempunyai tingkat keaktifan kurang atau tidak baik 34 responden, dimana 16 responden atau $88.9 \%$ memiliki pengetahuan baik dan 18 responden atau $58.1 \%$ memilki pengetahuan kurang atau tidak baik.

Hasil uji statistik diperoleh nilai $\mathrm{p}=0.035$ maka dapat disimpulkan ada perbedaan $(p$ value 0,05) proporsi pengetahuan antara responden yang memiliki tingkat keaktifan baik dengan responden yanmg memiliki tingkat keaktifan kurang atau tidak baik (ada hubungan antara pengetahuan dengan keaktifan penderita hipertensi dalam kegiatan prolanis). Dari hasil analisis diperoleh nilai OR yaitu 6.500 (95\% CI : 1.269-33.290) artinya responden yang 
memiliki pengetahuan kurang atau tidak baik mempunyai peluang 6.500 kali untuk keaktifan dalam kegiatan prolanis dibandingkan dengan responden yang memiliki pengetahuan baik.

hasil penelitian tentang hubungan antar tingkat sikap terhadap keaktifan penderita hipertensi dalam kegiatan prolanis di wilayah Puskesmas Merdeka Kota Bogor adalah sebagai berikut :

\section{Tabel 9 Hubungan antara Sikap Penderita Hipertensi terhadap Keaktifan dalam Kegiatan Prolanis di Puskesmas Merdeka Kota Bogor}

\begin{tabular}{|c|c|c|c|c|c|c|c|c|}
\hline \multicolumn{9}{|c|}{ Keaktifan } \\
\hline \multirow[t]{2}{*}{ Sikap } & \multicolumn{2}{|c|}{$\begin{array}{r}\text { Tidak } \\
\text { Aktif }\end{array}$} & \multicolumn{2}{|c|}{ Aktif } & \multicolumn{2}{|c|}{ Total } & \multirow[t]{2}{*}{ P.Value } & \multirow[t]{2}{*}{ OR } \\
\hline & $\mathrm{N}$ & $\%$ & $\mathrm{~N}$ & $\%$ & $\mathrm{~N}$ & $\%$ & & \\
\hline Setuju & 15 & $62.5 \%$ & 9 & $11.1 \%$ & 24 & 100.0 & & \\
\hline Tidak Setuju & 14 & $56.0 \%$ & 11 & $41.9 \%$ & 25 & 100.0 & 0.863 & $\begin{array}{c}1.310(0.418- \\
4.107)\end{array}$ \\
\hline Jumlah & 29 & $59.2 \%$ & 20 & $40.8 \%$ & 49 & & 100 & \\
\hline
\end{tabular}

Berdasarkan hasil diatas dapat diketahui bahwa hubungan antara sikap hubungan antara Sikap Penderita Hipertensi terhadap Keaktifan dalam Kegiatan Prolanis di Puskesmas Merdeka Kota Bogor dengan keaktifan responden dalam kegiatan prolanis yang mempunyai tingakat keaktifan aktif yaitu sebanyak 20 responden, dimana 9 responden atau $37.5 \%$ setuju (mendukung/positif) dan 11 responden atau 44.0\% tidak setuju (tidak mendukung/negatif). Sedangkan responden yang mempunyai tingkat keaktifan kurang atau tidak setuju sebanyak 29 responden, dimana 15 responden atau $62.5 \%$ setuju (mendukung/positif) dan 14 responden atau $56.0 \%$ tidak setuju (tidak mendukung/negatif).

Hasil uji statistic diperoleh nilai $p=1.000$ maka dapat disimpulkan tidak ada hipertensi dalam kegiatan prolanis di wilayah Puskesmas Merdeka Kota Bogor adalah sebagai berikut :

Tabel 10 Hubungan antara Dukungan Keluarga Penderita Hipertensi terhadap Keaktifan dalam Kegiatan Prolanis di Puskesmas Merdeka Kota Bogor

\begin{tabular}{|c|c|c|c|c|c|c|c|c|}
\hline \multicolumn{9}{|c|}{ Keaktifan } \\
\hline \multirow{2}{*}{$\begin{array}{c}\text { Dukungan } \\
\text { Keluarga }\end{array}$} & \multicolumn{2}{|c|}{$\begin{array}{r}\text { Tidak } \\
\text { Aktif }\end{array}$} & \multicolumn{2}{|c|}{ Aktif } & \multicolumn{2}{|c|}{ Total } & \multirow[t]{2}{*}{ P.Value } & \multirow[t]{2}{*}{ OR } \\
\hline & $\mathrm{N}$ & $\%$ & $\mathrm{~N}$ & $\%$ & $\mathrm{~N}$ & $\%$ & & \\
\hline $\begin{array}{c}\text { Tidak } \\
\text { Mendukung }\end{array}$ & 16 & $88.9 \%$ & 2 & $11.1 \%$ & 18 & 100.0 & \multirow{2}{*}{0.053} & \multirow{2}{*}{$\begin{array}{c}5.778(1.128- \\
29.605 \mathrm{CI})\end{array}$} \\
\hline Mendukung & 18 & $58.1 \%$ & 13 & $41.9 \%$ & 31 & 100.0 & & \\
\hline Jumlah & 34 & $69.4 \%$ & 15 & $30.6 \%$ & 49 & & 10 & \\
\hline
\end{tabular}

Berdasarkan hasil diatas dapat diketahui bahwa hubungan antar dukungan keluarga dengaan tingkat keaktifan responden dalam kegiatan prolanis yang mempunyai tingkat 
keaktifan aktif yaitu sebanyak 15 responden, dimana 2 responden atau $11.1 \%$ tidak mendukung dan 13 responden atau 41.9\% mendukung. Sedangkan responden yang mempunyai tingkat keaktifan kurang atau tidak aktif sebanyak 34 responden, dimana16 responden atau $88.9 \%$ tidak mendukung dan 18 responden atau 58.1\% mendukung.

Hasil uji statistik diperoleh nilai $\mathrm{p}=0.053$ maka dapat disimpulkan tidak ada perbedaan ( $p$-value 0.05) proporsi dukungan keluarga antara responden yang memiliki keaktifan aktif dengan responden yang memiliki tingkat keaktifan tidak aktif (tidak ada hubungan antara dukungan keluarga dengan keaktifan penderita hipertensi dalam kegiatan prolanis). Dari hasil diperoleh nilai OR yaitu 5.778 (95\% CI : 1.128-29.605), artinya responden yang memiliki dukungan keluarga yang tidak mendukung memiliki peluang 5.778 kali untuk keaktifan kurang atau tidak aktif dibandingkan dengan responden yang memiliki dukungan keluarga yang mendukung.

\section{PEMBAHASAN}

\section{Hubungan antara pengetahuan penderita terhadap keaktifan dalam kegiatan prolanis Tahun 2018}

Pengetahuan manusia diperoleh melalui pengalaman sehingga dapat berperilaku sesuai dengan pengetahuannya, ini terbukti bahwa perilaku yang didasari oleh pengetahuan akan lebih langgeng dari pada perilaku yang tidak baik didasari oleh pengetahuan, sebab pengetahuan adalah domain yang sangat penting untuk terbentuknya tindakan seseorang/overt behavior. Menurut Notoatmodjo (2010) mengutip dari teori Benyamin Bloom, membagi pengetahuan menjadi 6 tingkatan yaitu : tahu (know), memahami (comprehension), aplikasi (application), analisis (analysis), sintesis (synthesis), dan evaluasi (evaluation). Apabila seseorang akan melakukan suatu praktik/tindakan, terlebih dahulu ,mereka harus mengetahui apa dan bagaimana praktik tersebut (Notoatmodjo, 2012). Menurut Green (1980) menyatakan bahwa peningkatan pengetahuan tidak selalu menyebabkan perubahan perilaku, tetapi pengetahuan sangat penting diberikan sebelum individu melakukan suatu tindakan (praktik). Tindakan (praktik) akan sesuai dengan pengetahuan apabila individu menerima isyarat yang cukup kuat untuk memotivasi dia bertindak sesuai dengan pengetahuannya.

Berdasarkan hasil penelitian dapat diketahui bahwa hubungan antara pengetahuan dengan tingkat keaktifan responden dalam kegiatan prolanis yang mempunyai tingkat keaktifan aktif yaitu sebanyak 15 responden, dimana 2 responden atau $11.1 \%$ memiliki pengetahuan baik dan 13 responden atau 41.9\% memiliki pengetahuan kurang atau tidak baik. Sedangkan responden yang mempunyai tingkat keaktifan kurang atau tidak baik 34 responden, dimana 16 responden atau 88.9\% memiliki pengetahuan baik dan 18 responden atau $58.1 \%$ memilki pengetahuan kurang atau tidak baik.

Hasil uji statistik diperoleh nilai $\mathrm{p}=0.035$ maka dapat disimpulkan ada perbedaan $(p$ value 0,05) proporsi pengetahuan antara responden yang memiliki tingkat keaktifan baik dengan responden yang memiliki tingkat keaktifan kurang atau tidak baik ( ada hubungan antara pengetahuan dengan keaktifan penderita hipertensi dalam kegiatan prolanis). Dari hasil analisis diperoleh nilai OR yaitu 6.500 (95\% CI : 1.269-33.290) artinya responden yang memiliki pengetahuan kurang atau tidak baik mempunyai peluang 6.500 kali untuk keaktifan 
dalam kegiatan prolanis dibandingkan dengan responden yang memiliki pengetahuan baik.

Penelitian ini sejalan dengan Jois Ginting Fransiska (2017) bahwa ada hubungan antara pengetahuan dengan keaktifan responden dalam kegiatan prolanis di Puskesmas Merdeka Kota Bogor tahun 2017. Sejalan pula dengan penelitian dari Dirhan (2012) bahwa terdapat hubungan yang bermakna pengetahuan terhadap derajat diastole pasien hipertensi. Hasil penelitian ini juga sejalan dengan penelitian Nina Marlina (2012) yang menunjukan ada hubungan yang bermakna antara pengetahuan dengan keaktifan lansia dalam kelompok binaan. Hasil penelitian konsisten dengan penelitian Diyah Ekarini (2012) yang menunjukan bahwa terdapat hubungan yang bermakna antara tingkat pengetahuan dengan kepatuhan penderita hipertensi dalam menjalani pengobatan, begitu juga penelitian Mahfuz Bayu Purnomo Siswanto (2015) menunjukan bahwa $\mathrm{p}<0,05$ maka Ho ditolak, artinya terdapat hubungan yang signifikan antara tingkat pengetahuan dengan keaktifan kontrol penderita hipertensi di wilayah kerja Puskesmas Gatak Sukoharjo.

Penelitian ini bertentangan dengan penelitian yang dilakukan oleh Dian Puspitasari (2014) Menunjukan bahwa tidak ada hubungan antara tingkat pengetahuan dengan keaktifan dalam mengikuti kegiatan posyandu lansia.

Kurangnya interaksi penderita hipertensi terhadap layanan kesehatan dalam kegiatan prolanis bisa jadi penyebab rendahnya pengetahuan responden dalam memanfaatkan kegiatan tersebut. Hal ini bisa disebabkan dikarenakan masyarkat kurang memperoleh informasi tentang program kegiatan prolanis di puskesmas, hanya dengan lewat media cetak yang ada di puskesmas dan sosialisasi mengenai kegiatan prolanis belum efektif maksimak. Sesuai dengan teori Helath Model Belief (HBM) menyatakan bahwa tingkat pengetahuan seseorang dipengaruhi oleh informasi dan lingkungan tempat tinggalnya.

\section{Hubungan antara sikap responden terhadap keaktifan dalam kegiatan prolanis tahun 2018}

Sikap adalah reaksi atau respons seseorang yang masih tertutuip terhadap stimulus atau objek, manifestasi dari sikap tidak dapat langsung dilihat, tetapi hanya ditafsirkan terlebih dahulu dari perilaku yang tertutup. Dalam kehidupan sehari-hari sikap merupakan reaksi yang bersifat emosional terhadap stimulus sosial (Adnani, 2011). Sikap adalah kesiapan seseorang untuk bertindak secara tertentu terhadap hal-hal tertentu. Sikap dapat bersifat positif dan juga negatif, dalam sikap positif kecenderungan tindakan adalah mendekati, menyenangi, dan mengharapkan objek tertentu, sedangkan dalam sikap negatif terdapat kecenderungan untuk menjauh, menghindari, membenci, tidak menyukai objek tertentu (Wirawan, 1996). Menurut Notoatmodjo (2007) dikutip dari Allport (1954) sikap itu terdiri dari 3 komponen pokok yaitu, kepercayaan atau keyakinan, ide dan konsep terhadap objek artinya, bagaimana keyakinan dan pendapat atau pemikiran seseorang terhadap objek, kehidupan emosional atau evaluasi orang terhadap objek artinya bagaimana penilaian (terkandung didalamnya faktor emosi) orang tersebut terhadap objek; kecenderungan untuk bertindak (tend to behave) artinya adalah merupakan komponen yang bertindak atau berperilaku terbuka (tindakan). Ketiga komponen tersebut secara bersamaan membentuk sikap yang utuh (total attitude). Menentukan sikap yang utuh ini, pengetahuan, pikiran, keyakinan dan emosi memegang peranan penting. 
Berdasarkan hasil penelitian dapat diketahui bahwa hubungan antara sikap dengan keaktifan responden dalam kegiatan prolanis yang mempunyai tingkat keaktifan aktif yaitu sebanyak 20 responden , dimana 9 responden atau 37.5\% setuju (mendukung/positif) dan 11 responden atau $44.0 \%$ tidak setuju (tidak mendukung/negatif). Sedangkan responden yang mempunyai tingkat keaktifan kurang atau tidak setuju sebanyak 29 responden, dimana 15 responden atau 62.5\% setuju (mendukung/positif) dan 14 responden atau 56.0\% tidak setuju (tidak mendukung/negatif).

Hasil uji statistic diperoleh nilai $\mathrm{p}=1.000$ maka dapat disimpulkan tidak ada perbedaan ( $p$-value 0.05) proporsi sikap antara responden yang memiliki keaktifan aktif dengan responden ya ng memiliki keaktifan tidak aktif (tidak ada hubungan antara sikap dengan keaktifan penderita hipertensi dalam kegiatan prolanis). Dari hasil diperoleh nilai OR yaitru 1.310(0.418-4.107), artinya responden yang memiliki sikap tidak setuju (tidak mendukung/negatif) memiliki peluang 0.863 kali untuk keaktifan kurang atau tidak aktif dalam kegiatan prolanis dibandingkan dengan responden yang memiliki sikap setuju (mendukung/positif).

Hasil penelitian ini sejalan dengan penelitian yang dilakukan oleh Yunita (2016) menunjukan bahwa tidak ada hubungan bermakna antara sikap masyarkat dengan kejadian hipertensi.

Hasil penelitian ini berbeda dengan penelitian yang dilakukan oleh Jois Ginting Fransiska (2017) menunjukan bahwa adanya hubungan antara sikap dengan keaktifan responden dalam kegiatan Prolanis di Puskesmas Berastagi Kabupaten Karo Tahun 2017.

Peneliti berpendapat bahwa walaupun tingkat pengetahuan responden kurang akan tetapi sikap responden mayoritas setuju/aktif dengan mengikuti kegiatan prolanis tersebut, hal ini bisa disebabkan responden menganggap bahwa pelayanan dengan biaya langsung akan lebih mahal daripada pelayanan ketika ikut asuransi BPJS kesehatan. Tidak hanya itu saja, responden beranggapan bahwa dengan mengikuti serangkaian pengobatan dalam kegiatan prolanis di puskesmas lebih mudah terjangkau dibanding ke fasilitas pelayanan kesehatan yang lain (RS dan Klinik). Sikap responden yang aktif untuk ikut dalam kegiatan prolanis di Puskesmas akan dapat menambah pengetahuan dan keterampilan, hal ini disebabkan karena sikap yang mendukung adanya kegiatan pelayanan kesehatan akan mengakibatkan pelaksanaan kegiatan dapat berjalan sesuai harapan, sehingga responden jadi produktif untuk menjaga kesehatannya.

Soekidjo Notoatmodjo (2007) menyatakan bahwa kesehatan seseorang ditentukan oleh niat atau sikap orang tersebut terhadap pelayanan kesehatan (behavior intention) dukungan sosial dari masyarakat sekitar, ada atau tidaknya informasi tentang kesehatan dan fasilitas kesehatan. Lebih lanjut Green menyatakan bahwa perilaku kesehatan atau tingkat kesehatan seseorang ditentukan oleh sikap seseorang terhadap objek kesehatan. Semakin baik sikap seseorang terhadap kesehatan maka tingkat kesehatan seseorang tersebut juga akan semakin baik. 


\section{Hubungan antara dukungan keluarga responden terhadap keaktifan dalam kegiatan prolanis tahun 2018.}

Dukungan keluarga merupakan salah satu faktor yang menentukan tingkat kepatuhan pasien dalam menjalankan proses perawatan. Literatur perawatan kesehatan mengemukakan bahwa kepatuhan berbanding lurus dengan tujuan yang dicapai pada program pengobatan yang telah ditentukan (Bastable, 2002). Menurut Bomar (2004), bahwa dukungan emosional keluarga mempengaruhi terhadap status alam perasaan dan motivasi dari dalam mengikuti program terapi. Menurut Friedman (2003), dukungan penghargaan keluarga merupakan bentuk fungsi efektif keluarga terhadap lanjut usia yang dapat meningkatkan status psikososial lanjut usia.

Berdasarkan hasil penelitian dapat diketahui bahwa hubungan antara dukungan keluarga dengan tingkat keaktifan responden dalam kegiatan prolanis yang mempunyai tingkat keaktifan aktif yaitu sebanyak 15 responden, dimana 2 responden atau $11.1 \%$ tidak mendukung dan 13 responden atau 41.9\% mendukung. Sedangkan responden yang mempunyai tingkat keaktifan kurang atau tidak aktif sebanyak 34 responden, dimana16 responden atau 88.9\% tidak mendukung dan 18 responden atau 58.1\% mendukung.

Hasil uji statistik diperoleh nilai $\mathrm{p}=0.053$ maka dapat disimpulkan tidak ada perbedaan ( $p$-value 0.05) proporsi dukungan keluarga antara responden yang memiliki keaktifan aktif dengan responden yang memiliki tingkat keaktifan tidak aktif (tidak ada hubungan antara dukungan keluarga dengan keaktifan penderita hipertensi dalam kegiatan prolanis). Dari hasil analisis diperoleh nilai OR yaitu 5.778 (95\% CI : 1.128-29.605), artinya responden yang memiliki dukungan keluarga yang tidak mendukung memiliki peluang 5.778 kali untuk keaktifan kurang atau tidak aktif dibandingkan dengan responden yang memiliki dukungan keluarga yang mendukung.

Hasil penelitian ini sejalan dengan penelitian yang dilakukan oleh Elis Agustina (2017) Menunjukan bahwa tidak ada hubungan dukungan keluarga dengan keaktifan lansia dalam mengikuti kegiatan posyandu lansia.

Hasil ini tidak sejalan dengan penelitian Mahfuz Bayu Purnomo Siswanto (2013) yang menunjukan terdapat hubungan yang signifikan antara dukungan keluarga dengan keaktifan kontrol penderita hipertensi di wilayah Puskesmas Gatak Sukoharjo.

Peneliti berpendapat bahwa tidak adanya hubungan antara dukungan keluarga dengan keaktifan penderita hipertensi dalam kegiatan prolanis, kemungkinan keluarga sangat mendukung dengan adanya kegiatan prolanis di daerah sekitarnya oleh sebab itu tidak ada hubungan antara dukungan keluarga dengan keaktifan penderita hipertensi dalam kegiatan prolanis. 


\section{KESIMPULAN}

Berdasarkan pada hasil penelitian dan pembahasan dalam penelitian ini, dapat diambil dalam kesimpulan sebagai berikut:

1. Gambaran Karakteristik Umum (umur, jenis kelamin dan pendidikan), Pengetahuan, Sikap, Dukungan Keluarga dan Keaktifan Penderita Hipertensi di UPT Puskesmas Merdeka Kota Bogor Tahun 2018

Berdasarkan Karakteristik umur sebagian besar 43 responden terdapat (87.8\%) pada usia non-produktif $(>55)$. Berdasarkan jenis kelamin sebagian besar adalah perempuan sebanyak 38 orang (77.6\%). Bedasarkan karakteristik pendidikan sebagian besar responden adalah berpendidikan rendah (SD, SMP dan SMA) sebanyak 35 responden (71.4\%). Berdasarkan tingkat pengetahuan penderita sebagian besar responden memiliki pengetahuan tidak baik mengenai program pengelolaan penyakit kronis (Prolanis) sebanyak 30 responden (61.2\%). Berdasarkan tingkat sikap sebagian responden memiliki sikap setuju mengenai program penyelenggaraan penyakit kronis (Prolanis) sebanyak 29 responden (59.2\%). Berdasarkan tingkat dukungan keluarga penderita sebagian besar berkategori mendukung sebanyak 31 responden (63.3\%). Berdasarkan tingkat keaktifan penderita hipertensi sebagian besar 25 responden (51.0\%) termasuk kedalam kategori aktif dalam kegiatan Prolanis di UPT Pusksmas Merdeka Kota Bogor.

2. Terdapat Hubungan antara Pengetahuan dengan Keaktifan Penderita Hipertensi dalam Kegiatan Prolanis

3. Tidak ada Hubungan antara Sikap dengan Keaktifan Penderita Hipertensi dalam Kegiatan Prolanis

4. Tidak ada Hubungan antara Dukungan keluarga dengan Keaktifan Penderita Hipertensi dalam Kegiatan Prolanis

\section{Saran}

1. Puskesmas Merdeka Kota Bogor

a. Untuk meningkatkan keaktifan masyarakat terhadap program pengelolaan penyakit kronis peneliti menyarankan agar puskesmas merdeka kota bogor melakukan penyuluhan secara rutindan diharapkan dapat memaksimalkan kegiatan PROLANIS tersebut, sehingga memotivasi masyarakat untuk hadir dalam kegiatan yang dilakukan.

b. Perlu direncanakan dan member tugas kepada sebagian petugas kesehatan di puskesmas untuk melakukan kunjungan home visit

kerumah pasien, sehingga 4 aktivitas PROLANIS bisa berjalan maksimal sesuai dengan apa yang telah direncanakan oleh pmerintah dan BPJS Kesehatan.

2. Masyarakat

a. Masyarakat diharapkan dapat rutin berkunjung dalam kegiatan PROLANIS guna menjaga tubuh melalui pengukuran tekanan darah agar tetap terkontrol

3. Peneliti selanjutnya

a. Penelitian ini dapat menjadi referensi bagi peneliti selanjutnya dalam meneliti terkait Program Pengelolaan Penyakit Kronis dengan desain berbeda seperti penyakit kronis lain nya seperti gagal ginjal kronis, hipertiroid dan lainnya. Sehingga hasil penelitiannya menghasilkan informasi yang lebih lengkap. 


\section{DAFTAR PUSTAKA}

Adnani. (2011). Ilmu kesehatan Masyarakat. Nuha medika, jogyakarta.

Agustina, Elis. (2017). Hubungan Dukungan Keluarga dengan Keaktifan Lansia dalam Mengikuti Kegiatan Posyandu Lansia. Program Studi Ilmu Keperawatan Sekolah Tinggi Ilmu Kesehatan Insan Cendekia Medika Jombang 2017.

Amira, Iceu. dkk. (2017). Hubungan Pengetahuan Dengan Kepatuhan Diet Hipertensi pada Lansia di Kampung Honje Luhur Kelurahan Sukagalih Wilayah Kerja Puskesmas Pembangunan Kecamatan Tarogong Kidul Kabupaten Garut Tahun 2017. Fakultas Keperawatan Unpad Kampus Garut. Jurnal Kesehatan Bakti Tunas Husada Volume 18 Nomor 1 Februari 2018.

Astuti, Fidiar Tri. (2017). Hubungan Dukungan Keluarga dengan Keaktifan Lansia Mengikuti Posyandu Lansia di Posyandu Melati Klawisan Seyegan Yogyakarta. Program Studi Ilmu Keperawatan. Sekolah Tinggi Ilmu Kesehatan Jendral Ahmad Yani Yogyakarta 2017.

Azri, H. Gede N.I.P. (2017). Gambaran Karakteristik Penderita Hipertensi di Tingkat Kepatuhan Minum Obat diwilayah Kerja Puskesmas Kintamani I.

Azwar, Azrul. (2010). Pengantar Administrasi Kesehatan. Edisi ketiga. Jakarta: Binarupa Aksara.

A Nasution, A Maulana, D Kurniawan. (2019). BERSAMA MEMAJUKAN DESA. Abdi Dosen: Jurnal Pengabdian Pada Masyarakat 3 (2), 99-104

Budiman, A.R. (2013). Pengetahuan dan Sikap dalam Penelitian Kesehatan. Jakarta: Salemba Medika.

Cahyawaty, I.M. (2017). Hubungan Dukungan Keluarga Dengan Perilaku Lansia Dalam Pengendalian Hipertensi di Wilayah Puskesmas Pilang Kenceng Madiun. STIKES Bakti Husada Mulia Madiun 2017.

Chotimah, I., Oktaviani, S., \& Madjid, A. (2018). Evaluasi Program Tb Paru Di Puskesmas Belong Kota Bogor Tahun 2018. PROMOTOR, 1(2), 87-95.

Chotimah, I., Anggraini, D. (2018). Pemberdayaan Masyarakat Melalui Peningkatan Kualitas Pendidikan, Ekonomi, Kesehatan Dan Lingkungan. ABDIDOS 2 (1), 62-72.

Chotimah, I. (2017). Gambaran Perilaku Merokok Mahasiswa Universitas Ibn Khaldun Bogor 2013. HEARTY 5 (1).

Daeli Sonifati Fynce. (2017). Hubungan Tingkat Pengetahuan dan Sikap Pasie Hipertensi di UPTD Puskesmas Kecamatan Gunung Sitoli Selatan. Universitas Sumatera Utara: 2017

Deiby, 0. Lumempouw. Dkk. (2016). Pengaruh Senam Prolanis Terhadap Penyandang Hipertensi. Fakultas Kedokteran Universitas Sam Ratulangi Manado. Jurnal Volume 4 Nomor 1 Januari- Juni 2016.

Dewi, S. Hafizzurachman. (2016). Perilaku Pemanfaatan Posbindu di Wilayah Kerja Puskesmas Gunung Putri Tahun 2015. Skripsi. Fakultas Kesehatan Universitas Mh. Thamrin. Sekolah Tinggi Ilmu Kesehatan Indonesia Maju.

Dharma. (2011). Metode Penelitian Keperawatan. Jakarta: Trans Info Media.

Dika P. Destiani, et, al (2016). Evaluasi Penggunaan Obat Hipertensi Pada pasien Rawat Jalan di Fasilitas Kesehatan Rawat Jalan pada Tahun 2015 dengan Metode ATC/DDD.

Dirhan. (2012). Hubungan Pengetahuan, Sikap dan Ketaatan Berobat dengan Derajat Sistole dan Diastole Pasien Hipertensi di Puskesmas Sukamerindu Kota Bengkulu. Sekolah 
Tinggi Ilmu Kesehatan Tri Mandiri Sakti (STIKES TMS) Bengkulu. Jurnal Ilmiah Farmasi Vol. 9 No. 1 Tahun 2012.

Eliani, Elni. Dkk. (2014). Efektivitas Senam Sehat Prolanis BPJS Pada Pasien Hipertensi Rawat Jalan di Puskesmas Salak Kabupaten Pakpak Bharat. Program Studi Farmasi. Instititut Kesehatan Helvetia Medan Sumatra Utara Indonesia 2014.

Fitrianingtyas, Pertiwi, dan Rachmania, W. Faktor-Faktor yang Berhubungan dengan Kejadian Kurang Energi Kronis (KEK) pada Ibu Hamil di Puskesmas Warung Jambu Kota Bogor. HEARTY Jurnal Kesehatan Masyarakat. 2018;6(2):1-8.

Pertiwi, F. D., Hariansyah, M., \& Prasetya, E. P. (2019). FAKTOR RISIKO STUNTING PADA BALITA DIKELURAHAN MULYAHARJA TAHUN 2019. PROMOTOR, 2(5). https://doi.org/10.32832/pro.v2i5.2531

Pertiwi, F. D., Rahman, R. M., \& Lestari, D. W. (2018). Pemberdayaan masyarakat melalui bidang literasi di Desawaru Jaya. Jurnal ABDI DOSEN: Jurnal Pengabdian Pada Masyarakat, 2(2), 129-137. https://doi.org/10.32832/abdidos.v2i2.170 